\title{
Linguistics Relativity of the SumandoTributes in Pariaman Culture
}

\author{
Hilma Pami Putri ${ }^{1}$, Widya Syafitri ${ }^{2}$ \\ \{mrs.bentam@gmail.com ${ }^{1}$, widyasyafitri260780@gmail.com ${ }^{2}$ \} \\ Institut Agama Islam Negeri (IAIN) Bukittinggi, Indonesia ${ }^{1,2}$
}

\begin{abstract}
This article is an about the linguistic relativity of the sumando tribute in Pariaman culture. The objective of this research is to describe what Pariaman people implied in summoning the tributes to the sumando which is unique and not owned by other sumando around the region. The uniqueness of the tributes are sidi, sutan and bagindo that come from father to the son after getting merit, not from the uncle like Darek area. The descriptive qualitative was the design of this research. The data were obtained by doing the interview and observation of the Pariaman people and the sumando of Pariaman. The result revealed that most of Pariaman people summon the sumando politely as the appreciation of the position of sumando in RumahGadang. It is also implied that the sumando need to keep the behavior in the wife's society as well as the sumando has a big responsibility as the head of the family member
\end{abstract}

Keywords. Linguistics Relativity, Sumando, Tributes, Pariaman Culture

\section{Introduction}

Language shows the culture and consideration or thought of the peopleas well as where they belong. People can easily know one's origin from the language they used, the diction, the accent, the dialect they use and what is stated in the language when they are talking to others. There is the special thing from the language, or the term used by the people that is not owned by other culture. One of them is the gala or the tribute for thesumando or the son in law in Pariaman, Sumatera Barat. As the Rantau area, Pariaman is one of Minangkabau region in West Sumatera which is located near the beachbordering the Malacca strait and the south China sea[1]. There are many greetings words describes in Minangkabau society, it can be divided into general greetings, cultural greetings, religiousgreetings and position greetings[2].The cultural greeting is the special tributes for the sumando, the son in law in Pariaman society. Pariaman shows its uniqueness. The proverb of lain lubuk lain ikannya, lain daerah lain adatistiadatnya, which meansdifferent region has its different culture, is suitable for this condition. Some of the uniqueness are the matrilineal bloodline of culture and the custom of "laki-lakibabali" in marriage. The matrilinealbloodline is owned by the Minangkabau society, meanwhile the custom of "laki-lakibabali" is only owed by Pariaman. As the laki-lakibabali, it means, the brides' family needs to prepare some amount of money to be given to groom before getting merit. The money prepared calls as" uangjapuik". It becomes one of the prerequisites of getting married with the groomsThis custom has its meaning and adhere with Pariamanese and some of Padang people. 
After getting merit, the groom iscalled as SumandoRumahGadang, the special tribute to a man who become the husband of the sisters in matrilineal way. or the son in law of RumahGadang. The tributes made by all parties of the brides whose age is above the bride to the groom, starting from the parents in law, uncles, cousin, sisters and brothers in law. None of the family member can call the sumando by his name, even though the sumando's age is younger than the bride's family. For the family who's younger than the groom, they need to call uda, ajo as the bride's call which means brother. In spite of the summon of the bride's family to the sumando, the sumando's positionin RumahGadangis described as ash above the stump (abudiatehtunggua)[3]. This means that the position of sumando in his wife's family is very weak, the man does not make important decisions in his wife's family. It is just like when the stump flying by the wind and swept by the water. However, Pariaman people really respect to thesumando. This proverb hints that the position of sumando depends on the wife's family goodness to keep maintaining the sumando inside the family member because the groomlive in the bride's home after the wedding. When the sumando did something bad or cannot keep the position for good, the family member be ready to fly the ash. when the tornado come.

The special tributes for the sumandoin his wife society. are bagindo, sidi, and sutan[4].These three summons, has its own meaning and its own prestige to the bride and the bride's family members in the past. These three tributes aregiven from father to the son in patriarchate way, not to the nephew like in Darekarea like Bukittinggi, Batusangkar or Payakumbuh. Even, the tributes became one of the considerations of deciding uangjapuik of the sumando. In summoning the sumando, the Pariamanculture gives the tributes in front of name of the sumando. For example; BagindoWahyunis, Sidi Amril, or SutanImran. Ifthe tributes or the title is behind the name of the sumando or there two tributes mention in one it can be confirmed that the tributesis not from Pariaman. Nowadays, Pariamanwomen are already open to the outsider of Pariaman man. They want to get merit with the one who does not only come from Pariaman, also they are able to live in Pariaman or out of Pariaman. However, the Pariaman people keep respecting or keep summoning the sumando with tributes. It impacts to the tributes given to the sumando. To respecting the sumando, Pariaman people keep summoning the son in law with the special tributes for them. It has been the agreement of the Pariaman society to appreciate the son in law especially by giving the tributes. This article describes the about the linguistics relativity of the tributes given to the sumando, whether they live in Pariaman or livefar away from Pariaman.It expected to prove the relevance of the tributes nowadays or not

\section{The Related Literatures}

According to Whorfian hypothesis, language relativity is the ways in which language might impact thought[5]. It means that there was a strong relationship between language, culture and the mind of the speaker. It also could be said that the language appear is not only because of words, the person's condition and culture greatly influence the language used in daily communication. Then, the cultural pattern of the society can construct clauses to provide variation in the information and the politeness of the language. In RumahGadangPariaman, after getting merit, the grooms are already become apart of bride's live and society and the society pay a big attention the sumando. In this case, the sumandois the ambassador to keep the good side of him and the existence of him represent himself and his clan. It also requires the sumando to be careful because the sumando will always get the spotlight from the wife's 
family. The various terms are given by the Pariman people as an evaluation of their urangsumando's behavior based on the gestures and the behavior of the sumando. Itclassified the Sumando into four categoriesThey are SumandoNiniak Mamak,SumandoLangauHijau, SumandoLapiakBuruak, and SumandoKacangMiang[6]. SumandoNiniak Mamak is the sumando that can contribute to both races, his wife family and his chain. This sumando find a way out of something as wisely as possible. This sumando behavior and custom of the family is pleasing to the wife. This attitude is highly demanded on the role of each sumando in Minangkabau. This sumando can wisely treat himself good and his existence is prestigious in RumahGadang. SumandoLangauHijau or green larvasumando is the sumandowho the appearance is manly and convincing but the behaviour is not good. They like to get divorce in each village and leave the child everywhere. They tend to be as a base of commotion or the culprit[7]

Other is sumandokacangmiangor lentils. It is a kind of sumando that makes his wife anxious where he belong. It is because he raises or sharpens the problems that should not be raised.His work only interferes with the tranquility of the neighbor because of inciting and defamatory, or raising cattle that can interfere with the environment such as ducks, chickens, goats and others. His existence is a kind of nuts hair that effect to itches skin. The other one is sumandolapiakburuak, bad mat sumando.This sumando only concern on his wife and children without concerning about other issues around him. It just like forgot about the niece and hometown because his busyness and forgot about wife and children. This kind of sumando sometimes also said SumandoApakPaja, which serve only as seed to have children. worn Pandan mat in his wife's house. Each of these sumando appear as the evaluation of the act and the behavioir of the sumando inPariaman society. The sumando need to pay attention to the behavior, the way to interact with the wife's family and the way to think in every kind of situation. The best sumando ever is sumandoniniak mamak. This kind of sumando is really expected and blessing for the wife's family. The rest of sumando type do not need to cheat.

As the language relativity, the tributes adhere from father's bloodline. However, each of the tributes has its own background to mention. The Bagindotributes is applied to those who have the decent to Aceh authority who was in charge in Pariaman district in the past.This islineageof the kings.It was because Pariaman- Tiku areawas once ruled by the government of Aceh during the success of Sultan Iskandar Muda. Meanwhile, the tribute of sidiholds the title of Rasulullah, as Sayid and Sharif. Until now in Morocco, Sayid's descendants are still mentioned by Sidi. Sidi is of royal descent. Nowadays, all these three tributes occupy the same position and are treated the samein real life. There is almost no different among them. Pariaman people have a special way to appreciate people, not because the sumando has much money or sholeh, but the pariaman people respect the sumando just because the respect itself.

These tributes are the language the people use to interact with the sumando in Pariaman. The people never do something without the language or words. In this term, the people use the tributes for the sumando. They use the special term to indicate that the tributes are only for the sumando. Some of the expert expose the relativity of the language and the thought. How could Pariaman people do the same with the family members of the wife. Sapir and Wolf [8]decipher two hypothesis related to the language and the thought. They are linguistics relativity hypothesis and linguistics determinism. The linguistic hypothesis state that different language impact to the difference of the thought use by the people. Meanwhile, the structure of the language influences the people's perceptual. This situation happens in Pariaman society nowadays. There is no research mention about the tributes and the language relativity of the tributes of the sumando before this, hence, the researcher like to give her perspective toward the language relativity of the tributes. 


\section{Research Method}

The research method is a procedure or way to find out someting that has systematic steps in conducting research[9].In conducting this research, the design of thisresearch was a descriptive research.The descriptive research is used to describe the characteristics of the population or phenomenon being studied. It used to describe the phenomenon happen in Pariaman society especially about summoning the sumando with the special tributes. It is expected to know what the language relativity of the sumando tributes for Pariaman culture is. It also discusses about when where and how and why the tributes given to the Pariamansumando. The object of this research were the people in Pariaman who has son in law and describe about the language relativity in the tributes given to the sumando.The data collected though interview and observation to sumandoofPariamanand the way people in Pariaman summon the sumando.The data analyze to generate the description the data collection.

\section{Discussions}

The sumando tributesare included in the cultural address term in Pariaman. The tributes adhered to all the wife's family member whose age is older than the wife's sister or brother. The tributes given to the sumando right after the sumando become a part of the wife' s family member. The tributes are from the father's bloodline and never end until the son having the son and the son has the other son, and so on. From the tributes of the sumando appear in Pariman, it indicated that Pariaman people glorifying the guest. The sumandois very happy with the glorify tributes. There is politeness of the language appear on the summon. It proves that every people of the society, the family and also the people who knows about the wife's family, must summon the sumando with tributes. The special thing also happens when the sumando of Pariaman meet other people out of Pariman, when they know the man is the sumando of Parimana, they ask pretend to be as the sister of the wife and summoning the sumandoith the tributes of the kinship. Besides, the meaning inside the summon is the guest take the important position in family and aso culture. However, the sumando need to realize the position is only a guest that can be asked to leave the camp. This is the special thing from the culture. There is the thought that

According to [5], linguistic relativity comprises three main ideas.First is assuming that languages significantly different in the meanings of their words and syntactic constructions. It is supported by linguistic, anthropological, and psychological studies of word and phrasal meaning across languages.Second, the proposal holds that the semantics of a language can affect the way in which its speaker sperceive and conceptualizetheworld,and in the extreme, completely shape thought, a position known as linguistic determinism. Finally, given that language affectthinking,linguistic relativity holds that speakers of different languages think differently From these three main ideas, the tributes given to sumando in Pariaman effect to the way of Pariamanes thought of someone. When the Pariamanese know that they are talking to the PariamanSumando, they tend to greet or summon the sumandolike sidi, Sidi orbagindoas the kinship call. It happens to sumando that come out of Pariman. The sumando feel bless with that summon to him. They feel unite and close to the people at the moment of speaking. Meanwhile, when the Pariamanese meet the sumando coming from Pariaman, they pretend as the brother or sister that need to respect in certain way. They just need to summon the man with 
the word brother like diak or adik for the one who is younger than him and uda or ajo for the one who is older than him which mean brother. In daily life, the language relativity can be seen from the application of adatbasandisayaraksyarakbasandikitabullah, the culture based syaria, the syaria based Al-Qur'an. The culture shows that the guest needs to be respect and honored. It is in line with what Al-quran mention that respecting the guest that it becomes guidance and noble character. The host must show a good impression to the guest[10]. All of these tributes are the distinguished title. It can be seen from the line of the tributes, from the prophet. None of the Pariaman people not respecting the sumando and it still happen now.

\section{Conclusion}

The tributes must be maintained for present and for the future. Even though the modern times dominate, and the culture almost abandoned by society. It is because the sumando feel bless to be apart of Pariaman people. From the finding of this research, it could be concluded Pariaman culture is unique and friendly for the sumando for both sumando coming from Pariamanas well as out of Pariaman. It could be seen from the tribute given to the sumando from Pariaman and out of Pariaman region are the same. The summon given to the sumando is limited into three tributes, they are sidi, sutanandbagindo. These three tributes areadhered to respect the sumando in Pariaman. It also to indicates the position of sumando in RumahGadang. Besides the tributes given, it implied the meaning of the sumando is the one who hold the big responsibility to their nuclear family (wife and children) and the family of their wife. Besides, Pariaman society as well as Pariamansumando is proud of their culture especially the tribute mention to the sumando. The sumando tribute is already based on high thought, respecting the sumandomosywho will and has borne the burden of his citrus father. From these three tributes given to Sumando is equal. It is grateful as a modern Pariaman society to keep handling the culture of summoning the sumando tribute because the modern values followed to fulfill the the cultural values itself.

\section{References}

[1] Mansoer and M.D, Sedjarah Minangkabau. Jakarta: Bharata, 1970.

[2] P. P. dan P. Bahasa, Sistem Sapaan Bahasa Minangkabau. Jakarta: Departemen Pendidikan dan Kebudayaan, 1984.

[3] Z. Arifin, "Buru Babi: Politik Identitas Laki-Laki Minang Kabau," Humaniora, vol. 24, 2012.

[4] S. Hanani, Surau Aset Lokal Yang Tercecer. Bandung: Humaniora Utama Press, 2002.

[5] P. Wolff and K. J. Holmes, "Linguistic relativity," Wiley Interdiscip. Rev. Cogn. Sci., vol. 2, no. 3, pp. 253-265, May 2011.

[6] Y. Indra, "Analisis Semantik Metafora Warna Bahasa Minangkabau," Metalingua, vol. 15, no. 1, pp. 117-128, 2017.

[7] S. Diradjo, I, Dt., Tambo Alam Minangkabau. Bukittinggi: Kristal Multimedia, 2009.

[8] W. Widhiarso, "Pengaruh Bahasa terhadap Pikiran," pp. 1-16, 2005.

[9] H. Usman, Metodologi Penelitian Sosial. Jakarta: Bumi Aksara, 2008.

[10] Alquran and Terjemahan, Departemen Agama Republik Indonesia. Bandung: CV Daruss Sunnah, 2015. 